\title{
IN VITRO FUNGICIDE TESTING FOR CONTROL OF AVOCADO FRUIT ROTS
}

\author{
K.R. EVERETT and O.E. TIMUDO-TORREVILLA \\ HortResearch, Private Bag 92169, Mt Albert, Auckland, New Zealand \\ Corresponding author: Keverett@hortresearch.co.nz.
}

\begin{abstract}
Avocado fruit rots are most commonly caused by five fungi, Colletotrichum acutatum, C. gloeosporioides, Botryosphaeria parva, B. dothidea and Phomopsis sp. These rots are controlled by applying copper fungicides in the field on eight occasions during the season. Alternatives to standard copper fungicides were screened in the laboratory against these five pathogens for inhibition of spore germination and mycelial growth. In total seven fungicides were tested (boscalid, boscalid/pyraclostrobin, three formulations of copper hydroxide, copper hydroxosulphate and dithianon). The effective concentration at which $50 \%$ of spore germination or mycelial growth was inhibited $\left(\mathrm{EC}_{50}\right)$ was calculated for each fungicide. $\mathrm{The}^{\mathrm{EC}_{50}}$ values for spore germination were lowest for boscalid/pyraclostrobin and dithianon, and were $\leq 18.5 \mu \mathrm{g} / \mathrm{ml}$ against all five test fungi. For boscalid/pyraclostrobin all $\mathrm{EC}_{50}$ values were $\leq 7 \mu \mathrm{g} / \mathrm{ml}$. Copper formulations effectively inhibited spore germination by $50 \%$ at concentrations ranging from $0.1 \mu \mathrm{g} / \mathrm{ml}$ to $141 \mu \mathrm{g} / \mathrm{ml}$, but were less effective against mycelial growth.

Keywords: postharvest, fungicides, rots.
\end{abstract}

\section{INTRODUCTION}

Avocado fruit rots are caused most commonly by Colletotrichum acutatum, C. gloeosporioides, Botryosphaeria parva, B. dothidea and Phomopsis sp. (Hartill \& Everett 2002; Everett et al. 2007). These fungi infect through the sides of the fruit or through the cut pedicel to cause rots that express only when the fruit begin to ripen after harvest. The rots that infect through the side (body rots) are thought to infect the fruit latently throughout the season (Binyamini \& Schiffmann-Nadel 1972; Coates et al. 1993) necessitating a constant coverage with fungicide to prevent rots. There is a strong inverse linear relationship between number of fungicides applied and number of fruit affected by both body rots and stem end rots (Everett et al. 2007).

In comparative trials both in New Zealand and overseas (Willingham et al. 2001; Everett et al. 2005), copper was the most effective fungicide tested in the field. However, there have been concerns raised about the viability of long-term use of copper because of its accumulation in the soil and presumed impact on the environment (Merrington et al. 2002; Zwieten et al. 2004). There are several options to decrease copper use: (a) use new improved formulations that require less active ingredient for the same fungicidal effect, (b) alternate copper with other equally effective fungicides, (c) eliminate copper in favour of an equally effective alternative fungicide and (d) utilise cultural control methods. The work outlined in this paper is the first part of a screening programme to laboratory test alternative copper formulations and other fungicides for efficacy against the common avocado rot fungi. 


\section{METHODS}

A total of seven fungicides were tested. These are listed in Table 1.

Single-spore isolates of C. acutatum, C. gloeosporioides, B. parva, B. dothidea and Phomopsis were grown on Difco ${ }^{\circledR}$ Potato Dextrose Agar under UV and fluorescent lights on a 12:12 hour light:dark cycle at ca $20^{\circ} \mathrm{C}$. After 3-6 weeks, spores were harvested in sterile distilled water and the spore concentration adjusted to $10^{5}$ spores $/ \mathrm{ml}$ with the aid of a haemocytometer. Fungicide stock solutions were made in sterile deionised water to a concentration of 100 and $10,000 \mu \mathrm{g}$ a.i./ml, by w/v. The appropriate volume of each fungicide stock solution was added to $10 \mathrm{ml}$ of $1.5 \% \mathrm{w} / \mathrm{v}$ water agar in a $5 \mathrm{~cm}$ diameter sterile plastic Petri plate to achieve a range of final concentrations of $0,1,10,100$ and $1000 \mu \mathrm{g} / \mathrm{ml}$. There were three replicate plates per concentration. An aliquot of $100 \mu \mathrm{l}$ of spores $\left(10^{5}\right.$ spores $\left./ \mathrm{ml}\right)$ was placed on the surface of each Petri plate. After $4 \mathrm{~h}$ at $20^{\circ} \mathrm{C}$, the total numbers of spores in three microscope fields at a magnification of $\mathrm{x} 100$ were counted and the number of germinating spores was recorded (ca 20 spores per microscope field of view). Percentage spore germination per plate was calculated using the mean of three fields of view. At high fungicide concentrations, spores were stained with cotton blue to facilitate visualisation.

Fungal cultures were grown as for the spore germination tests, but mycelial plugs were removed from the edge of actively growing colonies (1-2 weeks of growth) with a sterilised $5 \mathrm{~mm}$ diameter cork borer and placed on Difco ${ }^{\circledR}$ potato dextrose agar (PDA) amended with the test fungicides (poison plates). Mycelial diameter was measured every 1-2 days for 10 days and plotted against time. Comparisons were made on the basis of mycelial growth rate, in $\mathrm{mm} /$ day, for the linear phase of the fungal growth curve. There were three replicate plates per treatment.

The concentrations at which $50 \%$ of spores failed to germinate $\left(\mathrm{EC}_{50}\right)$ were calculated by the following method. Logit transformations (logit $=\ln \{p /(1-p)\})$ of spore germination (as a proportion of germination on unamended agar) and mycelial growth (as a proportion of growth on unamended media) averaged over the three replicate plates were plotted against the logarithmic transformation of fungicide concentration to linearise the response. The slope of the linear portion of the transformed data was calculated by linear regression. The $\mathrm{EC}_{50}$ was calculated from each linear regression equation for $\mathrm{Y}=0$, that is the logit for $\mathrm{P}=0.5$ or $50 \%$. A constant value of 0.01 was added to non-transformed data to enable 0 and $100 \%$ values to be used in the calculations.

TABLE 1: Fungicides for control of avocado fruit rots tested and described according to active ingredient, chemical group and formulation.

\begin{tabular}{|c|c|c|c|c|}
\hline Fungicide product ${ }^{2}$ & Active ingredient & $\%$ a.i. & Chemical group & Formulation $^{1}$ \\
\hline Champ $^{\mathrm{TM}} \mathrm{DP}$ & copper hydroxide & 37.5 & copper & WDG \\
\hline Kocide $^{\circledR}$ 2000DS & copper hydroxide & 35 & copper & WDG \\
\hline Kocide $^{\circledR} 3000$ & copper hydroxide & 46.1 & copper & WP \\
\hline Cuprofix ${ }^{\circledR}$ Disperss ${ }^{\circledR}$ & $\begin{array}{l}\text { copper } \\
\text { hydroxosulphate }\end{array}$ & 20 & copper & WDG \\
\hline Delan $^{\circledR} 700 \mathrm{WG}$ & dithianon & 70 & quinones & WDG \\
\hline BAS $51001 \mathrm{~F}$ & boscalid & 50 & carboxamide & WDG \\
\hline BAS $51604 \mathrm{~F}$ & $\begin{array}{l}\text { boscalid/ } \\
\text { pyraclostrobin }\end{array}$ & $25.2 / 12.8$ & $\begin{array}{l}\text { carboxamide/ } \\
\text { strobilurin }\end{array}$ & WDG \\
\hline
\end{tabular}

${ }^{1} \mathrm{WDG}=$ water dispersed granules, $\mathrm{WP}=$ wettable powder.

${ }^{2}$ Champ is a trademark of Nufarm Americas Inc., Kocide is a trademark of Dupont, Cuprofix is a trademark of Cerexagri. Inc. and Delan is a trademark of BASF. 


\section{Statistical analysis}

The linear regression model and the data manipulation functions of MINITAB (version 9.0) were used for data analysis. The ORIGIN (version 7.5) graphical package was used for drawing graphs.

\section{RESULTS}

The fungicide that consistently and most effectively inhibited spore germination for all fungi tested was boscalid/pyraclostrobin at a concentration of $7 \mu \mathrm{g} / \mathrm{ml}$ and below (Table 2). Dithianon was the next most effective fungicide at a concentration of $18.5 \mu \mathrm{g} / \mathrm{ml}$ or less. The four formulations of copper inhibited spore germination of all the fungi tested but sometimes at high concentrations (viz. $140.9 \mu \mathrm{g} / \mathrm{ml}$ for Kocide ${ }^{\circledR}$ 3000 against $C$. gloeosporioides). The copper formulation that was effective at the lowest concentrations against spore germination of $B$. parva was Champ ${ }^{\mathrm{TM}} \mathrm{DP}$, the most effective against both species of Colletotrichum was copper hydroxosulphate, and the most effective against $B$. dothidea and Phomopsis sp. was Kocide ${ }^{\circledR} 3000$.

Boscalid/pyraclostrobin was the most effective fungicide inhibiting mycelial growth at a concentration of $0.1-0.8 \mu \mathrm{g} / \mathrm{ml}$ (Table 3). None of the other fungicides tested was effective at concentrations of this order.

TABLE 2: The effective concentration $(\mu \mathrm{g} / \mathrm{ml})$ at which $50 \%$ of spores failed to germinate $\left(\mathbf{E C}_{50}\right)$ of five avocado postharvest fungal pathogens treated with seven fungicides.

\begin{tabular}{lccccc}
\hline Fungicide & C. acutatum & $\begin{array}{c}\text { C. } \text { gloeo- } \\
\text { sporioides }\end{array}$ & B. parva & B. dothidea & $\begin{array}{c}\text { Phomopsis } \\
\text { sp. }\end{array}$ \\
\hline boscalid & $<0.1$ & $<0.1$ & 18.2 & 27.7 & 74.8 \\
boscalid/ & 7.0 & 0.2 & 2.3 & 0.2 & 0.2 \\
pyraclostrobin & 0.4 & 8.1 & 0.6 & 15.6 & 1.5 \\
Kocide 2000DS & 7.3 & 140.9 & 0.3 & 4.8 & 0.1 \\
Kocide 3000 & 1.0 & 57.6 & 0.1 & 11.4 & 2.7 \\
Champ DP & 0.1 & 2.3 & 4.0 & 98.2 & 1.5 \\
copper hydroxosulphate & $<0.1$ & $<0.1$ & 3.1 & 18.5 & $<0.1$ \\
dithianon & & & & &
\end{tabular}

TABLE 3: The effective concentration $(\mu \mathrm{g} / \mathrm{ml})$ at which $50 \%$ of mycelial growth was inhibited $\left(\mathrm{EC}_{50}\right)$ of five avocado postharvest fungal pathogens treated with seven fungicides.

\begin{tabular}{lrcrrr}
\hline Fungicide & C. acutatum & $\begin{array}{c}\text { C. gloeo- } \\
\text { sporioides }\end{array}$ & B. parva & B. dothidea & $\begin{array}{c}\text { Phomopsis } \\
\text { sp. }\end{array}$ \\
\hline boscalid & 1921.0 & $>^{1}$ & 837.7 & 2154.4 & $>^{1}$ \\
boscalid/ & 0.2 & 0.1 & 0.2 & 0.0 & 0.8 \\
pyraclostrobin & 2540.7 & 647.3 & 304.7 & 153.2 & 105.8 \\
Kocide 2000DS & 867.2 & 297.1 & 228.1 & 118.1 & 101.8 \\
Kocide 3000 & 346.7 & 257.2 & 1321.7 & 197.0 & 193.3 \\
Champ DP & 910.5 & 402.1 & 1645.3 & 749.9 & 543.0 \\
copper hydroxosulphate & 44.2 & 201.4 & 989.6 & 540.3 & 17.2 \\
dithianon & &
\end{tabular}

${ }^{1} \mathrm{EC}_{50}$ value is greater than the highest concentration used. 


\section{DISCUSSION}

The aims of this experiment were to find fungicides that are more effective against avocado rot fungi than the industry standard, copper, and to find copper formulations that could be used in lower amounts to control avocado rots in the field. Both results could lead to reduced use of copper fungicides in avocado orchards and consequent benefits to the environment (Merrington et al. 2002; Zwieten et al. 2004).

In this series of in vitro tests, there were differences between the copper formulations. Although Kocide ${ }^{\circledR} 3000$ was expected to be a superior product because of its more finely milled particle size, overall it did not perform as effectively as Kocide ${ }^{\circledR}$ 2000DS in spore germination tests. The copper formulations differed in effectiveness against each of the five tested fungi, but overall Kocide ${ }^{\circledR} 3000$ most effectively inhibited mycelial growth. Different copper formulations inhibited spore germination of different fungal species to varying degrees. For instance Champ ${ }^{T M}$ DP was the most effective fungicide against spore germination of $B$. parva, copper hydroxosulphate against both species of Colletotrichum, and Kocide ${ }^{\circledR} 3000$ against B. dothidea and Phomopsis. It was therefore difficult to ascertain which copper formulation was most effective at inhibiting spore germination.

The concentration of copper recommended for field use for controlling postharvest rots of avocados is in the order of $1000 \mu \mathrm{g} / \mathrm{ml}$. This is clearly well in excess of the concentration of copper required to inhibit spore germination for all five avocado pathogens tested, and for most formulations of copper is sufficient to inhibit mycelial growth. For the other fungicides, recommended field rates range from $126 \mu \mathrm{g} / \mathrm{ml}$ for dithianon to $300 \mu \mathrm{g} / \mathrm{ml}$ for boscalid. These estimates are based on recommendations for other crops. These field rates are far in excess of $\mathrm{EC}_{50}$ concentrations for spore germination determined in the laboratory. Boscalid is not recommended to be tested alone in poison plate tests using PDA (Spiegel \& Stammler 2006; Stammler \& Speakman 2006), and for this reason field rates of this fungicide may also be in excess of concentrations required to inhibit mycelial growth.

In vitro tests do not always accurately predict the performance of fungicides in the field (Everett \& Neilson 1996; Everett et al. 2005). For instance, fluazinam was the most effective fungicide using these in vitro techniques against all five avocado pathogens, but it did not control postharvest rots when applied in the field (Everett et al. 2005). However, poison plate tests and spore germination tests are commonly used as preliminary screening tests for fungicides (Corden \& Young 1962; Anahosur et al. 1977; Sharma \& Mohanan 1990; Everett \& Neilson 1996; Everett et al. 2005). These tests are useful for eliminating fungicides that are not likely to be effective in the field. More recently fungicides can have specific requirements for testing. The method recommended for testing the performance of boscalid and pyraclostrobin is a spore germination method in microtitre plates (Spiegel \& Stammler 2006; Stammler \& Speakman 2006), but it is not known if other fungicides will also perform well in this test.

On the basis of these tests, the fungicides boscalid/pyraclostrobin and dithianon have good prospects as alternatives to copper for the control of avocado fruit rots. However, previous laboratory and field fungicide screening has demonstrated that the results of laboratory tests have not necessarily been reflected in fungicide field trials. The most promising fungicides identified in this study will be further evaluated using detached fruit tests, before being evaluated in the field.

\section{ACKNOWLEDGEMENTS}

This study was supported by a grant from the MAF Sustainable Farming Fund, New Zealand Avocado Industry Council, BASF, Dupont and Nufarm. 


\section{REFERENCES}

Anahosur KH, Padaganur GM, Hegde RK 1977. Laboratory evaluation of fungicides against Cylindrocladium quinqueseptatum, the causal organism of seedling blight of Eucalyptus hybrid. Pesticides 11: 44-45.

Binyamini N, Schiffmann-Nadel M 1972. Latent infection in avocado fruit due to Colletotrichum gloeosporioides. Phytopathology 62(6): 592-594.

Coates LM, Muirhead IF, Irwin JAG, Gowanlock DH 1993. Initial infection processes by Colletotrichum gloeosporioides on avocado fruit. Mycological Research 97(11): 1363-1370.

Corden ME, Young RE 1962. Evaluation of eradicant soil fungicides in the laboratory. Phytopathology 52: 503-509.

Everett KR, Neilson HF 1996. Evaluation of fungicides for control of Alternaria leaf spot of Pseudopanax. New Zealand Journal of Crop and Horticultural Science 24: 267-272.

Everett KR, Owen SG, Cutting JGM 2005. Testing efficacy of fungicides against postharvest pathogens of avocado (Persea americana cv. Hass). New Zealand Plant Protection 58: 89-95.

Everett KR, Boyd LM, Pak HA, Cutting JGM 2007. Calcium, fungicide sprays and canopy density influence postharvest rots of avocado. Australasian Plant Pathology 36(1): 22-31.

Hartill WFT, Everett KR 2002. Inoculum sources and infection pathways of pathogens causing stem-end rots of 'Hass' avocado (Persea americana). New Zealand Journal of Crop and Horticultural Science 30(4): 249-260.

Merrington G, Rogers SL, Zwieten Lv 2002. The potential impact of long-term copper fungicide usage on soil microbial biomass and microbial activity in an avocado orchard. Australian Journal of Soil Research 40(5): 749-759.

Sharma JK, Mohanan C 1990. In vitro evaluation of fungicides against Cylindrocladium spp. causing diseases of Eucalyptus in Kerala, India. European Journal of Forest Pathology 21(1): 17-26.

Spiegel J, Stammler G 2006. Baseline sensitivity of Monilinia laxa and M. fructigena to pyraclostrobin and boscalid. Journal of Plant Diseases and Protection 113(5): 199-206.

Stammler G, Speakman J 2006. Microtiter method to test the sensitivity of Botrytis cinerea to Boscalid. Journal of Phytopathology 154: 508-510.

Willingham SL, Pegg KG, Coates LM, Cooke AW, Dean JR, Langdon PWB, Beasley DR 2001. Field management of avocado postharvest diseases. Acta Horticulturae No. 553 (Vol. 2): 435-438.

Zwieten Lv, Rust J, Kingston T, Merrington G, Morris S 2004. Influence of copper fungicide residues on occurrence of earthworms in avocado orchard soils. Science of the Total Environment 329(1/3): 29-41. 